\title{
A Review On Mechanical Behavior Of Cellulose AND NANOCEllulose COMPOSITES
}

\author{
Dinh Chi Pham ${ }^{1, *}$ and Tri-Dung Ngo ${ }^{2}$ \\ ${ }^{1}$ Global Engineering and Material Inc., \\ Princeton, NJ US \\ ${ }^{2}$ Biomass Conversion and Processing, InnoTech Alberta, \\ Edmonton, Alberta, Canada
}

\begin{abstract}
There are accelerating interests in the use of cellulose fiber-reinforced polymer composite materials in the past decades due to their great abundance, affordable cost, and their lightweight, recyclable and biodegradable characteristics. The research on nanocellulose composites with polymers has aslo made significant contributions to the development of functional and sustainable materials. This chapter attempts to provide a summary on the mechanical properties and behavior of cellulose fibers, nanocellulose, and the cellulose and nanocellulose composites. Addtionally, the challenges associated with cellulose and nanocellulose based composites with and without surface modifications are discussed.
\end{abstract}

Keywords: cellulose, nanocellulose, composites, biocomposite, nanocomposite

\section{REFERENCES}

[1] Nabi, S. D. \& Jog, P. J. (1999). Natural fiber polymer composites: A review. Advances in Polymer Technology, 18(4), 351-363.

[2] Georgopoulos, S. T., Tarantili, P. A., Avgerinos, E., Andreopoulos, A. G. \& Koukios, E. G. (2005). Thermoplastic polymers reinforced with fibrous agricultural residues. Polymer Degradation and Stability, 90(2), 303-312.

[3] Kalia, S., Dufresne, A., Cherian, B. M., Kaith, B. S., Luc, A., et al., (2011). Cellulose-based bio- and nanocomposites: A review. International Journal of Polymer Science, Volume 2011, Article ID 837875. Doi:10.1155/2011/837875.

[4] Andresen, M., Stenstad, P., Møretrø, T., Langsrud, S., Syverud, K., Johansson, L.-S., et al., (2007). Nonleaching antimicrobial films prepared from surface-modified microfibrillated cellulose. Biomacromolecules, 8(7), 2149-2155.

[5] Ichiro, S., Yasuhiko, N. \& Taisuke, I. (1962). Experimental determination of the elastic modulus of crystalline regions in oriented polymers. Journal of Polymer Science, 57(165), 651-660.

\footnotetext{
${ }^{*}$ Corresponding author: E-mail: dcpham@gem-innovation.com.
} 
[6] Tanaka, F. \& Iwata, T. (2006). Estimation of the elastic modulus of cellulose crystal by molecular mechanics simulation. Cellulose, 13, 509-517.

[7] Roman, M. (2009). Model Cellulosic Surfaces, ed., American Chemical Society, ISBN13: 9780841269651, DOI: 10.1021/bk-2009-1019.

[8] Lucia, A. L. \& Rojas, O. J. (2009). The Nanoscience and technology of Renewable Biomaterials, ed., John Wiley \& Sons, Ltd, Singapore.

[9] Moon, R. J., Martini, A., Nairn, J., Simonsen, J. \& Youngblood, J. (2011). Cellulose nanomaterials review: structure, properties and nanocomposites. Chemical Society Reviews, 40(7), 3941-3994.

[10] Bos, H. L., van den Oever, M. J. A. \& Peters, O. C. J. J. (2002). Tensile and compressive properties of flax fibres for natural fibre reinforced composites. Journal of Materials Science, 37(8), 1683-1692.

[11] Baley, C. (2002). Analysis of the flax fibres tensile behaviour and analysis of the tensile stiffness increase. Composites Part A: Applied Science and Manufacturing, 33(7), 939-948.

[12] Andersons, J., Spārniņš, E. \& Joffe, R. (2006). Stiffness and strength of flax fiber/polymer matrix composites. Polymer Composites, 27(2), 221-229.

[13] Gassan, J. \& Bledzki, A. K. (1996). Einfluß von haftvermittlern auf das feuchteverhalten naturfaserverst"arkter kunststoffe. Die Angewandte Makromolekulare Chemie, 236, 129138.

[14] Maloney, T. M. (1995). in International encyclopedia of composites, S. M. Lee S. M., Rowell, R. M., Eds., p. 656, VCH Publishers, New York, USA, 1995.

[15] Mieck, K. P., Nechwatal, A. \& Knobelsdorf, C. (1994). Potential applications of natural fibres in composite materials. Melliand Textilberichte, 75 (11), 892-898.

[16] Mukherjee, P. S. \& Satyanarayana, K. G. (1986). An empirical evaluation of structureproperty relationships in natural fibres and their fracture behaviour. Journal of Materials Science, 21(12), 4162-4168.

[17] Ashby, M. F. \& Jone, D. R. H. (1989). Engineering materials 1: an introduction to their properties and applications. Pergamon Press, Oxford.

[18] Daniel, I. M. (2006). Engineering mechanics of composite materials/ Isaac M. Daniel, Ori Ishai. New York : Oxford University Press 2nd Ed.

[19] Mott, L., Groom, L. \& Shaler, S. (2002). Mechanical properties of individual southern pine fibers. Part II. Comparison of earlywood and latewood fibers with respect to tree height and juvenility. Wood Fiber Sci., 34, 221-237.

[20] Eichhorn, S. J. \& Young, R. J. (2001). The Young's modulus of a microcrystalline cellulose. Cellulose, 8(3), 197-207.

[21] Rusli, R. \& Eichhorn, S. J. (2008). Determination of the stiffness of cellulose nanowhiskers and the fiber-matrix interface in a nanocomposite using Raman spectroscopy. Applied Physics Letters, 93(3), 033111.

[22] Lahiji, R. R., Xu, X., Reifenberger, R., Raman, A., Rudie, A. \& Moon, R. J. (2010). Atomic force microscopy characterization of cellulose nanocrystals. Langmuir: the ACS Journal of Surfaces and Colloids, 26(6), 4480-4488. 
[23] Guhados, G., Wan, W. \& Hutter, J. L. (2005). Measurement of the elastic modulus of single bacterial cellulose fibers using atomic force microscopy. Langmuir: the ACS journal of surfaces and colloids, 21(14), 6642-6.

[24] Hsieh, Y. C., Yano, H., Nogi, M. \& Eichhorn, S. J. (2008). An estimation of the Young's modulus of bacterial cellulose filaments. Cellulose, 15(4), 507-513.

[25] Eichhorn, S. J. \& Davies, G. R. (2006). Modelling the crystalline deformation of native and regenerated cellulose. Cellulose, 13(3), 291-307.

[26] Stephan, R. \& Jürgen, B. (1995). Theoretical investigations on the structure and physical properties of cellulose. Macromolecular Theory and Simulations, 4(4), 725-743.

[27] Diddens, I., Murphy, B., Krisch, M. \& Müller, M. (2008). Anisotropic elastic properties of cellulose measured using inelastic X-ray scattering. Macromolecules, 41(24), 9755-9759.

[28] Eichhorn, S. J., Young, R. J. \& Davies, G. R. (2005). Modeling crystal and molecular deformation in regenerated cellulose fibers. Biomacromolecules, 6(1), 507-513.

[29] Eichhorn, S. J., Sirichaisit, J. \& Young, R. J. (2001). Deformation mechanisms in cellulose fibres, paper and wood. Journal of Materials Science, 36(13), 3129-3135.

[30] Northolt, M. G., den Decker, P., Picken, S. J., Baltussen, J. J. M. \& Schlatmann, R., (2005). Polymeric and Inorganic Fibers, vol. 178, 1-108.

[31] Halpin, J. C. \& Kardos, J. L. (1976). The Halping-Tsai equations a review. Polymer Engineering and Science, 16(5), 344-352.

[32] Pham, D. C., Sun, X. S., Tan, V. B. C., Chen, B. \& Tay, T. E. (2012). Progressive failure analysis of scaled double-notched carbon/epoxy composite laminates. International Journal of Damage Mechanics, 21(8), 1154-1185.

[33] Pham, D. C. \& Sun, X. S. (2012). Experimental and computational studies on progressive failure analysis of notched cross-ply CFRP composite. International Journal of Computational Materials Science and Engineering, 1(3), 1-15.

[34] Majumdar, A., Mukhopadhyay, S., Yadav R. \& Mondal, A. K. (2011). Properties of ringspun yarns made from cotton and regenerated bamboo fibres. Indian Journal of Fibre \& Textile Research, 36, 18-23.

[35] Pham, D. C. \& Narayanaswamy, S. (2014). An optimization tool for impact analysis of composite structures. Procedia Engineering, 75, 3-8.

[36] Pham, D. C. \& Narayanaswamy, S. (2015) An effective modeling strategy for drop test analysis of composite curved beam. In 56th AIAA/ASCE/AHS/ASC Structures, Structural Dynamics, and Materials Conference.

[37] Pham, D.C., Sridhar, N., Qian, X., Sobey, A.J., Achintha, M. \& Shenoi, A. (2016). A review on design, manufacture and mechanics of composite risers. Ocean Engineering, 112, 82-96.

[38] Gauthier, R., Joly, C., Coupas, A. C., Gauthier, H. \& Escoubes, M. (1998). Interfaces in polyolefin/cellulosic fiber composites: Chemical coupling, morphology, correlation with adhesion and aging in moisture. Polymer Composites, 19(3), 287-300.

[39] Wambua, P., Ivens, J. \& Verpoest, I. (2003). Natural fibres: can they replace glass in fibre reinforced plastics? Composites Science and Technology, 63(9), 1259-1264.

[40] Bos, H. L., Müssig, J. \& van den Oever M. J. A. (2006). Mechanical properties of shortflax-fibre reinforced compounds. Composites Part A: Applied Science and Manufacturing, 37(10), 1591-1604. 
[41] Garkhail, S. K., Heijenrath, R. W. H. \& Peijs, T. (2000). Mechanical properties of naturalfibre-mat- reinforced thermoplastics based on flax fibres and polypropylene. Applied Composite Materials, 7(5), 351-372.

[42] Nishino, T. (2004). Natural fiber sources. In Green composites: Polymer composites and the environment, CRC Press, Boca Raton, Fla, USA.

[43] Espert, A., Vilaplana, F. \& Karlsson, S. (2004). Comparison of water absorption in natural cellulosic fibres from wood and one-year crops in polypropylene composites and its influence on their mechanical properties. Composites Part A: Applied Science and Manufacturing, 35(11), 1267-1276.

[44] Thwe, M. M. \& Liao, K. (2003). Durability of bamboo-glass fiber reinforced polymer matrix hybrid composites. Composites Science and Technology, 63(3), 375-387.

[45] Pavithran, C., Mukherjee, P. S. \& Brahmakumar, M. (1991). Coir-glass intermingled fibre hybrid composites. Journal of Reinforced Plastics and Composites, 10(1), 91-101.

[46] Tobias, B. C. (1993). Tensile and Impact behaviour of natural fiber-reinforced composite materials. in Proceedings of the International Conference on Advanced Composite Materials, Chandra, T.D.A. K. Ed., The Minerals, Metals and Materials Society.

[47] Mueller, H. D. (2004). Improving the impact strength of natural fiber reinforced composites by specifically designed material and process parameters. IJN Winter.

[48] de Bruijn, J. C. M. (2000). Natural fibre mat thermoplastic products from a processor's point of view. Applied Composite Materials, 7(5), 415-420.

[49] Gassan, J. (2002). A study of fibre and interface parameters affecting the fatigue behaviour of natural fibre composites. Composites Part A: Applied Science and Manufacturing, 33(3), 369-374.

[50] Savastano, H., Santos, S. F., Radonjic, M. \& Soboyejo, W. O. Fracture and fatigue of natural fiber-reinforced cementitious composites. Cement and Concrete Composites, 31(4), 232-243.

[51] Towo, A. N. \& Ansell, M. P. (2008). Fatigue of sisal fibre reinforced composites: Constantlife diagrams and hysteresis loop capture. Composites Science and Technology, 68(3), 91524.

[52] Yuanjian, T. \& Isaac, D. H. (2007). Impact and fatigue behaviour of hemp fibre composites. Composites Science and Technology, 67(15), 3300-3307.

[53] Ahmad, F. \& Bajpai, P. K. (2018). Evaluation of stiffness in a cellulose fiber reinforced epoxy laminates for structural applications: Experimental and finite element analysis. Defence Technology, 14, 278-286.

[54] Lee, S. H., Wang, S., Pharr, G. M. \& Xu, H. (2007). Evaluation of interphase properties in a cellulose fiber-reinforced polypropylene composite by nanoindentation and finite element analysis. Composites Part A, 38, 1517-1524.

[55] Helbert, W., Cavaille, J. Y. \& Dusfesne, A. (1996). Thermoplastic nanocomposites filled with wheat straw cellulose whiskers. Part I: Processing and mechanical behavior. Polymer Composites, 17(4), 604-611.

[56] Sturcova, A., Davies, G. R. \& Eichhorn, S. J. (2005). Elastic modulus and stress-transfer properties of tunicate cellulose whiskers. Biomacromolecules, 6(2), 1055-1061. 
[57] Elazzouzi-Hafraoui, S., Nishiyama, Y., Putaux, J. L., Heux, L., Dubreuil, F. \& Rochas, C. (2008). The shape and size distribution of crystalline nanoparticles prepared by acid hydrolysis of native cellulose. Biomacromolecules, 9(1), 57-65.

[58] Matos Ruiz, M., Cavaillé, J. Y., Dufresne, A., Gérard, J. F. \& Graillat, C. (2000). Processing and characterization of new thermoset nanocomposites based on cellulose whiskers. Composite Interfaces, 7(2), 117-131.

[59] Chakrabarty, A. \& Teramoto, Y. (2018). Recent advances in nanocellulose composites with polymers: A guide for choosing partners and how to incorporate them. Polymers, 10, 517, DOI:10.3390/polym10050517.

[60] Bahar, E., Ucar, N., Onen, A., Wang, Y., Oksüz, M., Ayaz, O., Ucar, M. \& Demir, A. (2012). Thermal and mechanical properties of polypropylene nanocomposite materials reinforced with cellulose nano whiskers. Journal of Applied Polymer Science, 125 (4), 2882-2889. DOI: 10.1002/app.36445. 